\title{
BAHASA MELAYU RENDAH DALAM SURAT KONGSI CINA LANFONG DI KALIMANTAN BARAT PERIODE KOLONIAL
}

\author{
A LOW MALAYLANGUAGE \\ IN LANFONG-CHINESE KONGSI'S LETTER \\ IN COLONIAL WEST KALIMANTAN
}

\author{
Dana Listiana \\ Balai Pelestarian Nilai Budaya Kalimantan Barat \\ Jln. Letjen Sutoyo Pontianak \\ dana.listiana@gmail.com
}

Diterima tanggal 31 Agustus 2018

Disetujui tanggal 10 Desember 2018

\begin{abstract}
This paper aims to understand one of languages which was used in the colonial archives and its sociological context based on the function and when the language had been used. The literature study demonstrates that Low Malay was commonly used in the colonial archives of West Borneo. The source studied is a letter from a Lanfong Kongsi in West Kalimantan to the Dutch colonial government. Lanfong Kongsi is a Chinese association which is Chinese political entity community that started from a group of economic activities that has gold mining as their main activity in Mandor. Those activities became the reasons for writing the letters reviewed in this article. A letter indicates that Low Malay had been used as a diplomatic language even by nonspeaker groups. It interestingly occured when the colonial government had not yet officially called on the language as an intermediate language.
\end{abstract}

Keywords: Low Malay, archive, Lanfong, kongsi, and letter.

\begin{abstract}
ABSTRAK
Tulisan ini bertujuan untuk menggambarkan salah satu bahasa sumber arsip periode kolonial dan memahami konteks sosiologis bahasa berdasarkan fungsi dan waktu ketika bahasa tersebut digunakan. Berdasarkan studi kepustakaan diketahui bahwa sumber periode kolonial juga meliputi arsip berbahasa Melayu Rendah. Sumber arsip yang ditelaah adalah surat permohonan dari Kongsi Lanfong di
\end{abstract}


Handep, Vol. 2, No. 1, Desember 2018

Kalimantan Barat kepada Pemerintah Hindia Belanda. Kongsi Lanfong adalah sebuah kongsi Cina, entitas politik komunitas Cina yang bermula dari kelompok aktivitas ekonomi, dengan aktivitas utama berupa penambangan emas di Mandor. Aktivitas tersebut pulalah yang melatari penulisan surat yang ditelaah dalam artikel ini. Surat menunjukkan bahwa bahasa Melayu Rendah digunakan sebagai bahasa diplomatik bahkan oleh kelompok yang bukan penuturnya. Hal ini menarik karena berlaku di kala pemerintah kolonial belum resmi menetapkan bahasa Melayu sebagai bahasa pengantar.

Kata kunci: Melayu Rendah, arsip, Lanfong, kongsi, dan surat.

\section{A. PENDAHULUAN}

Penulisan sejarah periode kolonial menuntut penggunaan sumber arsip. Arsip yang dinilai primer karena diciptakan se-zaman dengan peristiwa pada periode tersebut, dianggap mampu memberi bukti-bukti (evidence) tentang masa lalu (Lohanda, 2011: 2; Alamsyah, 2018: 153-155).

Sayangnya, penempatan arsip pada derajat kualitas sumber tertinggi cenderung digunakan sebatas informasi tersurat. Padahal, arsip tidak hanya memuat data tekstual tetapi juga menceritakan suasana, waktu, dan urgensi sosio-kultural ketika arsip itu dibuat (Gaillet, 2010: 28).

Sepaham dengan Gaillet, Ann Laura Stoler mengajukan studi arsip dengan pendekatan etnografis. Ia mengingatkan pengguna arsip di masa kini akan hakikat penciptaan dan penyusunan arsip, yakni dalam rangka penyelenggaraan negara kolonial. Oleh karena itu, menurutnya, arsip akan memuat taksonomi struktur birokrasi yang ambisius dan cenderung membuat klaim-klaim yang berpijak pada kategori perbedaan sosial. Stoler menolak pemahaman arsip sebagai mesin informasi dengan "menelan bulat-bulat segala informasi yang ada". Stoler menegaskan arsip seharusnya diperlakukan sebagai penataan dan penyelarasan tiada henti dari orangorang dan keyakinannya sebagai ruang tempat rasa dan alur emosi diabstraksi dari rasionalitas politik dan tidak menempatkan arsip sebagai "wadah penyimpanan" kekuasaan negara tetapi sebagai "pergerakan nyata di medan perang". Pendeknya, Stoler menekankan pentingnya pemahaman tentang bagaimana sebuah arsip diproduksi dan diperlakukan selayaknya etnografi (Stoler, 2009: 31-33). ${ }^{1}$

Untuk itu, Stoler mengajak para pengkaji arsip untuk mencermati bagaimana konteks ${ }^{2}$ dibangun dari

\footnotetext{
1 Pengkaji kolonial seharusnya menjadi terampil mengidentifikasi jarak antara hal normatif, kategori yang dikenakan atas perbedaan sosial yang bertolak belakang dengan perubahan, dan hubungan sosial yang nyata (Stoler, 2009: 32).

${ }^{2}$ Konteks yang diacu oleh pengkaji arsip nantinya menjadi pengarah narasi penulisan,
} 
sebuah arsip. Konteks akan mengarahkan pada seperangkat klaim kebenaran yang dapat menghapus validitas (konteks) yang lain atau kerangka parameter yang dapat menjelaskan peristiwa. Salah satu hal yang disarankan Stoler adalah memahami bahasa yang digunakan dalam surat atau laporan sebagai pijakan untuk dapat membicarakan lebih dari sekedar konvensi struktur birokrasi (taksonomi kolonial) (Stoler, 2009: 17-53).

Pentingnya memahami bahasa arsip juga disampaikan oleh Mona Lohanda. Penguasaan bahasa harus dikuasai mulai dari struktur dan gaya penulisan (dari pembuat arsip), struktur kalimat, gaya bahasa, ekspresi, kosakata, ejaan, dan perkembangan kebahasaan yang berlaku seiring perkembangan masyarakat penuturnya. Seperti Stoler, Lohanda menekankan pentingnya pemahaman situasi kontekstual yang melatarbelakangi penciptaan arsip. Oleh karena itu, ia menyatakan bahwa keberhasilan sejarawan (atau pengkaji arsip secara umum) bertumpu pada pemahaman kata dan bahasa yang merupakan modal dalam penafsiran data. Pemahaman bahasa memerlukan 'rasa bahasa' (sense of language) dan pengetahuan

menandai kisi-kisi kejelasan di mana agenagen kolonial berusaha untuk menunjukkan penguasaan mereka terhadap situasi lokal dan keahlian analitis mereka sendiri (Stoler, 2009: 46-51). seputar bahasa tersebut (Lohanda, 2011: 10-11; 98).

Jika kita mempelajari arsip kolonial Kalimantan Barat, salah satunya dapat diakses melalui Arsip Nasional Republik Indonesia (ANRI), maka tidak lengkap tanpa menemui koleksi arsip daerah. Koleksi arsip daerah (gewestelijke archieven) Kalimantan Barat dapat ditelusuri melalui katalog Inventaris Arsip Borneo Westerafdeeling yang berkode K.34. Koleksi K.34 memuat 378 bundel tahun 1609-1890. Berbagai jenis arsip mulai dari kontrak perjanjian, korespondensi sampai laporan pejabat kolonial sejak masa Vereenigde Oost-Indische Compagnie (VOC) dapat ditemukan melalui telusur katalog tersebut. Sebagian besar arsip berbahasa Belanda tertuang dalam laporan umum (Algemeene Verslag), laporan politik (Politieke Verslag), laporan perjalanan seperti Algemeene Verslag van de Boven-Binnenlanden ter West Kuste Borneo Gelegen aan de Rivier Kapoúas dan laporan khusus berupa kondisi kelompok masyarakat atau aktivitas tertentu yang dianggap penting oleh pemerintah kolonial seperti laporan tentang masyarakat Cina, bajak laut, dan pertambangan (ANRI, 2016: 9-13; ANRI, TT: 6-34).

Meski sebagian besar arsip berbahasa Belanda, arsip daerah Kalimantan Barat memuat koleksi arsip berbahasa Melayu baik bertuliskan aksara Arab maupun Latin. Arsip dalam huruf Arab Melayu antara lain 
Handep, Vol. 2, No. 1, Desember 2018

ditemukan dalam surat-surat Sultan Pontianak. Arsip dalam huruf Latin antara lain ditemukan dalam catatan keluarga Kesultanan Pontianak. Ada pula temuan unik arsip berbahasa Melayu dalam bundel "Ikhtisar Singkat Mengenai Industri dan Perdagangan di Borneo Tahun 1849". ${ }^{3}$ Dalam bundel bernomor 177 tersebut terselip sebuah surat dari kongsi ${ }^{4}$ Cina 'Lanfong' berhuruf Latin dan berbahasa Melayu yang sepintas berbeda dengan surat atau catatan dari kesultanan.

Membaca surat dari Kongsi Lanfong tersebut memunculkan dua pertanyaan. Pertama, apa jenis bahasa Melayu yang digunakan dalam surat tersebut? Kedua, mengapa jenis bahasa tersebut digunakan oleh Kongsi Lanfong dalam berkorespondensi dengan pemerintah Hindia Belanda? Pertanyaan kedua muncul menimbang

3 Bundel ini rusak parah sehingga sebagian besar halaman tidak dapat dibuka. Oleh karena itu, penulis yang mengakses naskah pada 2009 hanya dapat membuka bagianbagian yang tidak rapuh dan tidak dapat memeroleh informasi judul arsip dalam versi asli. Kini, bundel ini tidak lagi dapat diakses oleh penelusur di Arsip Nasional RI.

${ }^{4}$ Kongsi berasal dari kata si berarti pengelolaan dan kong berarti perusahaan (komersial) berarti milik bersama/ usaha umum dalam bahasa Cina-Mandarin. Kongsi dikonotasikan sebagai kelompok "suram" atau geng yang bersatu dengan tujuan memperjuangkan kepentingan sendiri dalam bahasa Belanda. Adapun kongsi di Kalimantan Barat mulanya berupa serikat persaudaraan yang diikat oleh aktivitas ekonomi dan berkembang menyerupai sebuah negara lengkap dengan alat kelengkapan negara (Yuan dan Vleming dalam Listiana, 2017: 47-48). kultur berbahasa yang hidup di komunitas tersebut tidak menggunakan bahasa Melayu. Komunitas Cina di luar Jawa, termasuk Kalimantan, sebagian besar hidup di pedesaan, bukan di perkotaan di mana bahasa Melayu hidup dan berkembang sebagai alat komunikasi (Sumardjo, 2004: 39-41). Hal ini diperkuat oleh penelitian Hari Poerwanto terkait klasifikasi dan penggunaan bahasa pada komunitas Cina di daerah tersebut. Poerwanto berpendapat bahwa komunitas Cina di Kalimantan Barat tidak dapat dikategorikan sebagai 'peranakan' dalam makna sosio-kultural sebagaimana 'peranakan' di Jawa

5 Istilah 'peranakan' yang dewasa ini berkembang adalah pemaknaan sosiokultural yang mengacu pada kajian komunitas Cina di Jawa. Para sinolog, dari dalam dan luar Indonesia, yang lokus kajiannya terbatas di Jawa merumuskan bahwa 'peranakan' adalah sebutan bagi orang Cina yang secara kultural tidak lagi berorientasi pada negeri leluhur dan tidak berbicara bahasa Cina di rumah (Rafferty, 1984: 247). Akan tetapi, makna 'peranakan' tersebut tidak dapat digunakan terhadap komunitas Cina di Kalimantan Barat. Poerwanto, yang mengacu pada riset James C. Jackson tentang komunitas Cina di pertambangan emas Kalimantan Barat, menyatakan bahwa istilah 'peranakan' di Kalimantan Barat lebih sering dipakai untuk membedakan antara mereka yang merupakan keturunan dari orang tua atau generasi di atasnya yang melakukan perkawinan campuran dengan imigran yang baru datang atau keturunannya (Poerwanto, 2005: 83). Istilah tersebut mengacu pada pemahaman umum masyarakat Kalimantan Barat bahwa para pendatang Cina yang mulamula datang ke Indonesia dahulu adalah para lelaki yang kemudian menikahi perempuan setempat. 
karena masih menggunakan 'bahasa ibu' Negeri Cina secara aktif sebagai bahasa komunikasi anggota komunitas (Poerwanto, 2005: 81-84). Kedua pertanyaan tersebut diharapkan mampu mengantar tulisan ini untuk mengidentifikasi salah satu bahasa sumber dalam arsip Kalimantan Barat dan memahami konteks sosio-historis dari penggunaan bahasa Melayu Rendah.

Sebagai referensi, penulis meninjau sejumlah tulisan tentang bahasa Melayu yang dituturkan oleh komunitas Cina di wilayah Nusantara pada masa kolonial. Artikel yang ditinjau berjudul "Baba Malay Dialect" karya Tan Chee-Beng (1980); "Language of the Chinese of Java, An Historical Review" karya Ellen Rafferty (1984); "Baba Malay. An Introduction to the Language of the Straits-born Chinese" karya W. G. Shellabear (1913); dan "The Development of Articles in Baba Malay" karya Elzbieta Thurgood (2001).

Shellabear mengajukan istilah 'Baba Malay' (Melayu Baba) untuk menyebut bahasa Melayu yang dituturkan oleh komunitas Cina di sekitar Semenanjung Malaya ('Straits Settlement'). Shellabear berargumen Melayu Baba berawal sebagai bahasa bisnis di Penang, Malaka, dan Singapura yang kemudian berkembang di Jawa dan beberapa daerah lain di Indonesia masa kolonial Belanda. Menurut Shellabear, persebaran bahasa di dua daerah terakhir itu memunculkan dua terminologi bahasa Melayu, yaitu 'Melayu Tinggi' dan 'Melayu Rendah'. 'Melayu Rendah' yang merupakan bahasa percakapan (colloquial language) ini berkembang berbeda dengan Melayu Baba. Berfokus pada perkembangan (berdasarkan pelafalan, idiom, dan kosakata yang khas) bahasa Melayu Baba yang lebih banyak menyerap bahasa Cina, Shellabear juga membandingkan dengan 'Melayu Rendah' yang lebih banyak menyerap bahasa Melayu. ${ }^{6}$

Tan menganalisis ciri-ciri yang menonjol dari varian bahasa (dialek) Melayu Baba berupa bentuk serapan atau peralihan kosakata Cina, Indonesia, dan Inggris serta perbedaan fonologi, leksikal, semantik, dan sintaksis. Sejalan dengan Shellabear, Tan dalam konteks historis berargumen bahwa Melayu Baba dikembangkan oleh imigran Cina pendahulu dan keturunannya di Semenanjung Malaya dan Singapura dalam interaksi sosial mereka dengan orang Melayu setempat. Melayu Baba yang berfungsi sebagai bahasa perdagangan kemudian berkembang di area Malaka, Singapura, dan Jakarta (Batavia). Melayu Baba berkembang khas di daerah-daerah

\footnotetext{
${ }^{6}$ Bahasa Melayu-Rendah menurut Shellabear merupakan bahasa percakapan sehari-hari, bukan bahasa tulis. Oleh karena itu, Melayurendah memiliki sifat adaptasi terhadap bahasa komunikasi setempat dan dengan berbagai "lidah" penutur di berbagai tempat di Nusantara (the mixed multitude of various tongues who live in the southern part of the Archipelago) (Shellabear, 1913: 49-50).
} 
Handep, Vol. 2, No. 1, Desember 2018

tersebut karena dipengaruhi oleh kondisi sosial, ekonomi, dan politik setempat.

Rafferty membuat ulasan historis mengenai bahasa tutur peranakan Cina-Jawa yang ia istilahkan 'Melayu Rendah'. Memulai pembahasan dengan membuat perbandingan umum antara 'Melayu Rendah' dengan 'Melayu Tinggi', Rafferty lebih banyak menjelaskan perkembangan historis 'Melayu Rendah'. Secara khusus dalam cakupan penelitiannya, Rafferty menyimpulkan bahwa 'Melayu Rendah' di Jawa yang dituturkan oleh peranakan Cina merupakan asimilasi bahasa Jawa, perairan Jawa dan Belanda, serta kebudayaan Cina Jawa (dipengaruhi oleh literatur sastra Jawa dan Cina). ${ }^{7}$

Thurgood membahas analisis sinkronisasi bahasa Melayu Baba pada cerita narasi di surat kabar "Bintang Timor" pada abad ke-19. Thurgood menganalisis bentuk asimilasi bahasa imigran Cina dengan bahasa Melayu dari frekuensi tekstual dan fungsi wacana 'ini' dan 'itu' dalam narasi.

Artikel-artikel di atas membahas perkembangan bahasa Melayu yang dituturkan komunitas Cina di

\footnotetext{
${ }^{7}$ Melayu-rendah merupakan istilah generik yang mencakup seluruh varian bahasa Melayu percakapan yang tumbuh di Nusantara selama berabad-abad. Melayurendah berupa Melayu Betawi yang hidup di lingkungan multietnik. Melayu-rendah juga berupa dialek peranakan Cina (Rafferty, 1984: 252).
}

Semenanjung Malaya dan perluasannya di Indonesia, khususnya Jakarta dan wilayah kultur Jawa sebelum kemerdekaan. Artikel-artikel karya para linguis dan antropolog tersebut dalam tulisan ini berfungsi sebagai acuan pustaka untuk menganalisis bahasa yang digunakan dalam surat Kongsi Lanfong. Lebih jauh lagi, pendekatan linguistik yang dipelajari dari studi pustaka di atas diharap mampu berkontribusi bagi peneliti sejarah dalam memahami sumber.

Permasalahan di atas akan diulas dengan metode studi pustaka berupa sumber arsip sebagai bahan kajian dan berbagai pustaka yang digunakan sebagai bahan telaah. Adapun dalam mengulas permasalahannya, penulis akan menggunakan konsep yang bersifat operasional dan fungsional yang disampaikan oleh para ahli bahasa. Konsep operasional dari Rafferty dan konsep penjelas dari Kees Groeneboer.

Konsep 'Melayu Rendah' yang diajukan Rafferty (1984: 247-248) dapat dikatakan merupakan bahasa oral (bukan bahasa tulis hingga abad ke-19), tidak memiliki standar, dan memiliki banyak variasi dialek yang bertolak belakang dengan 'Melayu Tinggi' sebagai bahasa bergengsi di kalangan istana dan literasi Melayu. Rafferty berargumen bahasa tersebut terbentuk melalui penyesuaian dengan dialek daerah dan bahasa setempat serta bahasa asing yang dituturkan oleh komunitas di lingkungan tertentu. Secara fungsi, Rafferty menyatakan 
bahwa 'Melayu Rendah' umumnya digunakan sebagai alat komunikasi dan perdagangan antaretnis yang tidak memiliki bahasa seragam.

Untuk memberi daya penjelas, penulis menggunakan pendekatan sosiologi bahasa dari Groeneboer (1995). Konsep sosiologi bahasa digunakan dalam membahas penggunaan bahasa Melayu oleh kongsi Cina dalam berkomunikasi dengan Pemerintah Hindia Belanda. Sosiologi bahasa adalah pendekatan untuk menelaah berfungsinya (variasi) bahasa dalam masyarakat. Pendekatan ini bukan menelaah perubahan bahasa secara internal yang berkembang dalam perjalanan waktu, namun berfokus pada variasi bahasa yang digambarkan sebagai gejala masyarakat.

\section{B. HASIL DAN BAHASAN}

\section{Surat Kongsi Cina Berbahasa Melayu}

Bahasa Melayu diketahui telah digunakan sebagai bahasa tulis dalam bentuk karya sastra dan surat resmi. Penggunaan bahasa Melayu disebut oleh Lembaga Arsip Nasional sebagai bahasa yang paling banyak digunakan dalam surat-surat diplomatik sejak abad ke-17 dan abad ke-16 dibandingkan dengan bahasa daerah lain di Nusantara. Karenanya, bahasa Melayu disebut sebagai bahasa diplomatik (https:// sejarah-nusantara.anri.go.id/ diplomatic-letters/, diakses pada 1 Maret 2018; Collins, 2005: 29-31; 4445).

Akan tetapi, dalam risetnya tentang perkembangan kesusasteraan 'Melayu Rendah', Jakob Sumardjo menyatakan bahwa bahasa tulis Melayu pada periode yang disebut di atas adalah 'Melayu Tinggi' yang memang berlaku di lingkungan istana. Adapun 'Melayu Rendah' kala itu masih digunakan sebatas bahasa tutur. 'Melayu Rendah' diketahui mulai digunakan untuk bahasa tulis pada paruh kedua abad ke19 dan itu pun bukan berupa tulisan resmi seperti surat diplomatik.

Gejala lain mengenai penggunaan bahasa 'Melayu Rendah' pada tulisan resmi ditunjukkan oleh surat dari Kongsi Lanfong kepada Pemerintah Hindia Belanda. 
Handep, Vol. 2, No. 1, Desember 2018

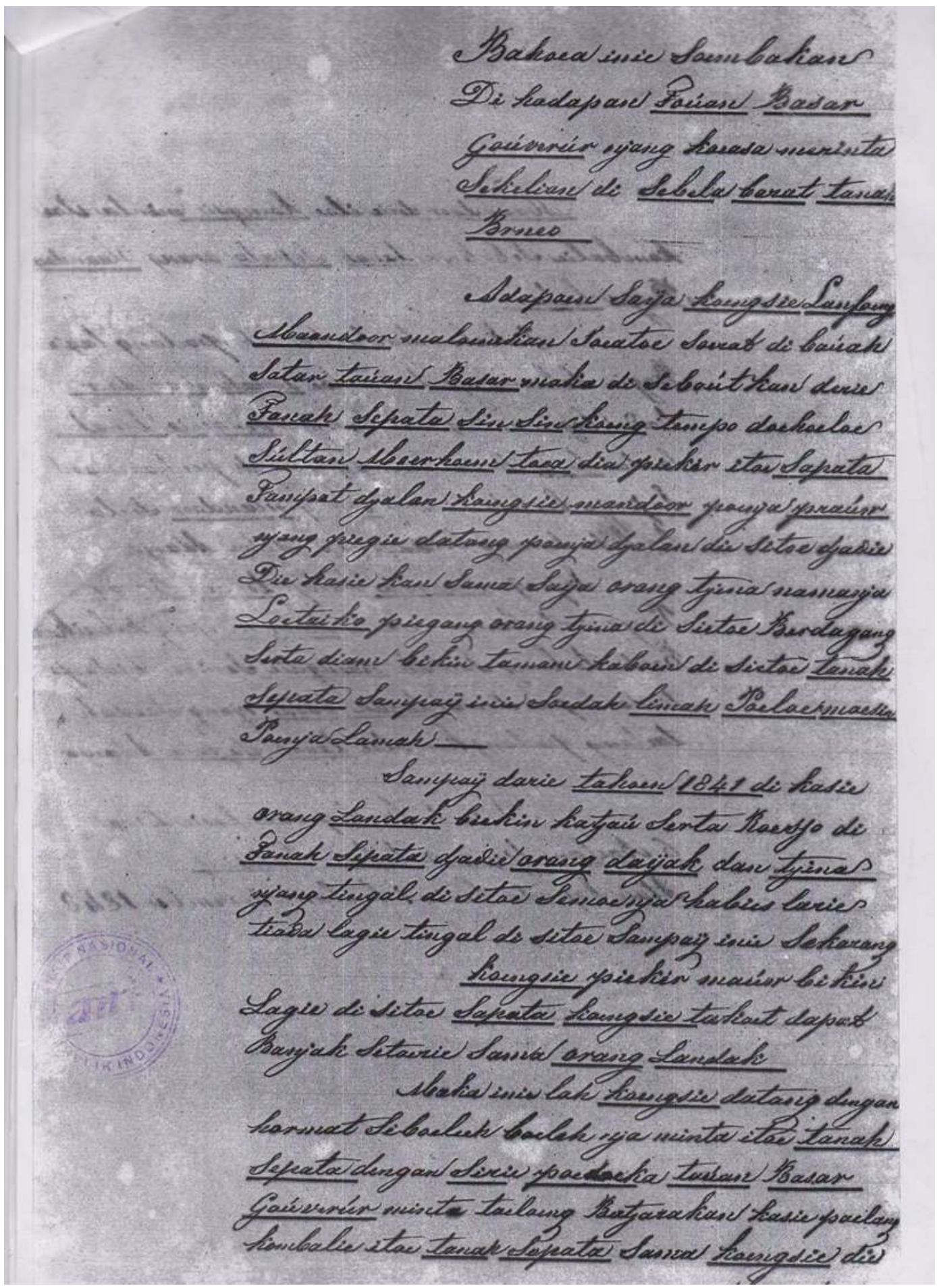

Gambar 1a. Surat Kongsi Lanfong kepada Pemerintah Hindia Belanda tahun 1848.

Sumber: ANRI, Inventaris Arsip Borneo Westerafdeeling No. 177. 


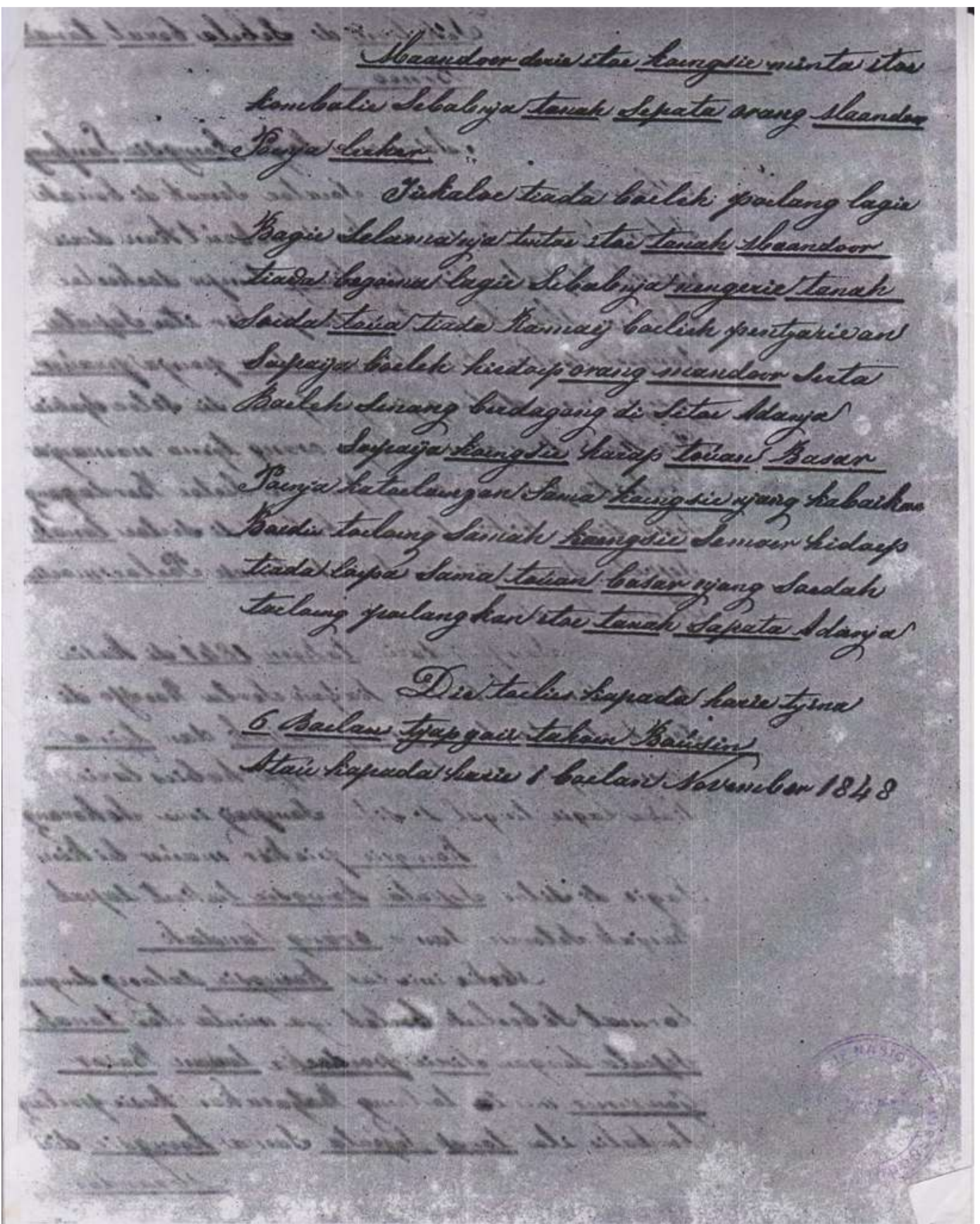

Gambar 1b. Surat Kongsi Lanfong kepada Pemerintah Hindia Belanda tahun 1848. Sumber: ANRI, Inventaris Arsip Borneo Westerafdeeling No. 177. 
Handep, Vol. 2, No. 1, Desember 2018

Berikut transkripsinya.

"Bahoea inie soembahkan Di hadapan Toúan Basar Goúvernúr njang koeasa merinta Sekelian di Sebela barat tanah $\underline{\text { Brneo }}$

Adapoen saija koengsie Lanfong Maandoor maloemkan soeatoe soerat di baúah latar toúan Basar maka di seboútkan derie Tanah Sepata $\underline{\text { Sin Sin koeng tempo doehoeloe Súltan Maerhoem toea dia piekir itoe Sapata }}$ Tampat djalan koengsie mandoor poenja praúw njang piegie datang poenja djalan die sitoe djadie Die kasie kan sama saija orang tjina namanja Loetaiko piegang orang tjina di sitoe Berdagang serta diam bikin tamam kaboen di sitoe tanah Sepata Sampaij inie Soedah limah Poeloe moesin Poenja lamah

Sampaij darie tahoen 1841 di kasie orang Landak biekin katjau Serta Roesjo di Tanah Sepata djadie orang Daijak dan tjina njang tinggal di sitoe Semoenja habies larie tiada tingal di sitoe sampaij inie sekarang

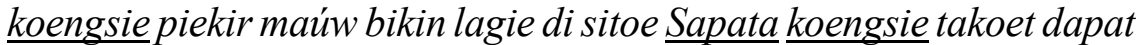
Banjak Setoerie Sama orang Landak

Maka inie lah koengsie datang dengan hormat Siboeleeh boeleh nja minta itoe tanah Sepata dengan Sirie padoeka toúan Basar Goúvernúr minta toeloeng Bertjarakan kasie poelang kembalie itoe tanah Sepata sama koengsie die Maandoor darie itoe koengsie minta itoe kembalie Sebabnja tanah Sepata orang Maandoor Poenja leebar

Jikaloe tiada boeleh poelang lagie Bagie Selamanja tentoe itoe tanah Maandoor tiada begoena lagie Sebabnja nengerie tanah soeda toúa tiada Ramaij boelieh pentjariean Soepaija boeleh hiedoep orang mandoor serta Boeleh senang berdagang di sitoe Adanja

Soepaija koengsie harap toúan Basar Poenja katoeloengan Sama koengsie njang kabaikan Boedie toeloeng Samah koengsie Semoer hidoep tiada loepa sama toúan basar njang Soedah toeloeng poelangkan itoe tanah Sapata Adanja

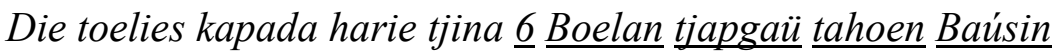
Atau kapada harie i boelan November 1848"

(ANRI, Inventaris Arsip Borneo Westerafdeeling No. 177, 1848).

\section{Karakter Linguistik Melayu Rendah Dalam Surat Kongsi}

Berdasarkan transkripsi surat di atas, penulis mengidentifikasi situasi kebahasaan pada komunitas Kongsi
Lanfong dengan menelaah karakteristik bahasa surat. Telaah dilakukan dengan membandingkan analisis konstruksi bahasa yang dilakukan Rafferty pada 'Melayu Rendah' dan Shellabear pada 
Melayu Baba, salah satu bentuk dialek Melayu Cina yang berkembang di Semenanjung Malaya.

Berdasarkan riset Rafferty (1984: 257-260), dialek Melayu Rendah memiliki kekhasan konstruksi sintaksis. Sejumlah kekhasan tersebut juga muncul pada surat Kongsi Lanfong seperti berikut.

1. Pola kata ganti penunjuk berupa: demonstrative adjective (kata sifat penunjuk) + noun (kata benda), dapat dilihat dari penggalan kalimat berikut.

... Súltan Maerhoem toea dia piekir itoe Sapata Tampat djalan...

... habies larie tiada tingal di sitoe sampaij inie sekarang koengsie piekir...

2. Pola kata kepemilikan berupa: possessor (pemilik) + punya + possessed (yang dimiliki), ditunjukkan oleh penggalan kalimat berikut.

...Tampat djalan kongsie Mandoor poenja prauw...

... tanah Sepata orang Maandoor poenja leebar...

3. Bentuk kata kerja kausatif berupa: verb (kata kerja) + verb (kata kerja) dengan kata bikin sebagai kata kerja pertama, seperti pada penggalan kalimat berikut.

... orang tjina di sitoe berdagang serta diam bikin tamam kaboen di sitoe...

... koengsie piekir maúw bikin lagie di sitoe Sapata...
4. Penggunaan kata sambung yang sebagaimana kata ganti penunjuk orang atau benda yang berfungsi untuk menghubungkan kalimat yang menerangkan kata benda. Berikut sejumlah kutipan yang termuat dalam surat.

... orang Daijak dan tjina njang tinggal di sitoe...

... toúan basar njang Soedah toeloeng poelangkan itoe tanah Sapata...

Selain Rafferty, penulis juga menelaah karakteristik kebahasaan surat Kongsi Lanfong dengan riset Shellabear (1913: 51-63). Shellabear fokus pada bentuk kata ganti (pronoun), idiom, dan pelafalan dalam tulisan. Shellabear berargumen, kedua bentuk tersebut menunjukkan kecenderungan bahasa yang terbentuk. Apakah lebih dipengaruhi oleh bahasa Cina yang kemudian dapat dikategorikan sebagai dialek Melayu Baba atau dipengaruhi oleh bahasa Melayu dan bahasa setempat atau disebut dialek Melayu Rendah.

Shellabear (1913: 57) mengamati penggunaan akhiran (sufiks) -kan yang kerap digunakan oleh komunitas Cina. Penggunaan-kan juga muncul pada surat Kongsi Lanfong seperti berikut.

...koengsie Lanfong Maandoor maloemkan soeatoe soerat...

... die sitoe djadie Die kasie kan sama saija...

Sebaliknya, kata depan (preposisi) yang menurut Shellabear (1913: 57) sering digunakan oleh orang Melayu justru kerap muncul pada surat Kongsi. 
Handep, Vol. 2, No. 1, Desember 2018

Misalnya, penggunaan kata bagi yang bermakna untuk atau pun sama yang digunakan bergantian dengan pada, akan, dan dengan.

... Die kasie kan sama saija... (sama bermakna pada)

... Banjak Setoerie Sama orang Landak... (sama bermakna dengan)

... tiada boeleh poelang lagie Bagie Selamanja... (bagi bermakna untuk)

...minta itoe tanah Sepata dengan

Sirie padoeka... (dengan bermakna pada).

Selain itu, penggunaan kata atau frasa kesopanan (polite phraseology) yang menurut Shellabear (1913: 57) lazim digunakan orang Melayu juga muncul dalam surat Kongsi. Kata smbah (sembah) atau kata lain untuk kelas masyarakat yang lebih tinggi berikut ditujukan kongsi kepada pemerintah Hindia Belanda.

Bahoea inie soembahkan di hadapan Toúan Basar Goúvernúr...

... minta itoe tanah Sepata dengan sirie padoeka toúan Basar Goúvernúr...

Shellabear (1913: 58) juga mencermati kelalaian komunitas Cina dalam melafalkan kosakata Melayu yang kerap muncul dalam bahasa tulis di surat Kongsi. Kelalaian pelafalan berupa hilangnya huruf $h$ pada kata yang diakhiri huruf $h$, sebagai berikut.

... koeasa merinta sekelian di sebela barat...

... orang Landak biekin katjau serta Roesjo [rusuh]...

Sebaliknya, kelalaian pelafalan yang kerap dipraktikkan oleh komunitas
Cina berupa penyisipan huruf $h$ di tengah kata tidak muncul pada surat kongsi, seperti berikut.

...saija koengsie Lanfong...

Menurut Shellabear (1913: 58), kata saya kerap disisipi huruf $h$ menjadi sahya. Penyisipan serupa dikenakan pada kata baru menjadi bharu ataupun saja menjadi sahaja.

Shellabear (1913: 54-55) juga mengidentifikasi sering digunakannya idiom bahasa Cina oleh komunitas Cina. Idiom Cina yang muncul pada surat kongsi yaitu koengsie (kongsi), loetaiko (abang), dan penanggalan Cina bulan tjapgaü dan tahun Baúsin.

Selain membandingkan dengan sejumlah riset kebahasaan, pengenalan karakter bahasa Melayu pada surat Kongsi Lanfong juga dilakukan dengan membandingkan manuskrip dari lingkungan istana yang diduga tergolong Melayu Tinggi, sebagaimana para ahli bahasa sampaikan tentang penggunaan bahasa di Istana Melayu. Manuskrip pertama berikut adalah kutipan catatan yang dibuat oleh Pangeran Bendahara Kesultanan Pontianak.
“...Sjahdan lagie maka tijada brapa antara nja maka njang di per toean moeda radja Adjie pan mamanggillah sekelian orang- orang di dalam negrie Pontianak memariksakan hal padoeka Srie pangeran Sjarief Abdul Rachman Noor Alam inie handak Kita angkat ija berpangkat nama Sulthan, maka sekelian bangsa bangsa di dalam 
negrie Pontianak itoe pan sekelian

nja berkata soeka, serta lagie menjoeroh pergie Ka negrie Mampawa dan Ka negrie Matan, dan Ka negrie Landak dan $\mathrm{Ka}$ negrie Koeboe..." (Inventaris Arsip Borneo Westerafdeeling No. 233, 1855).

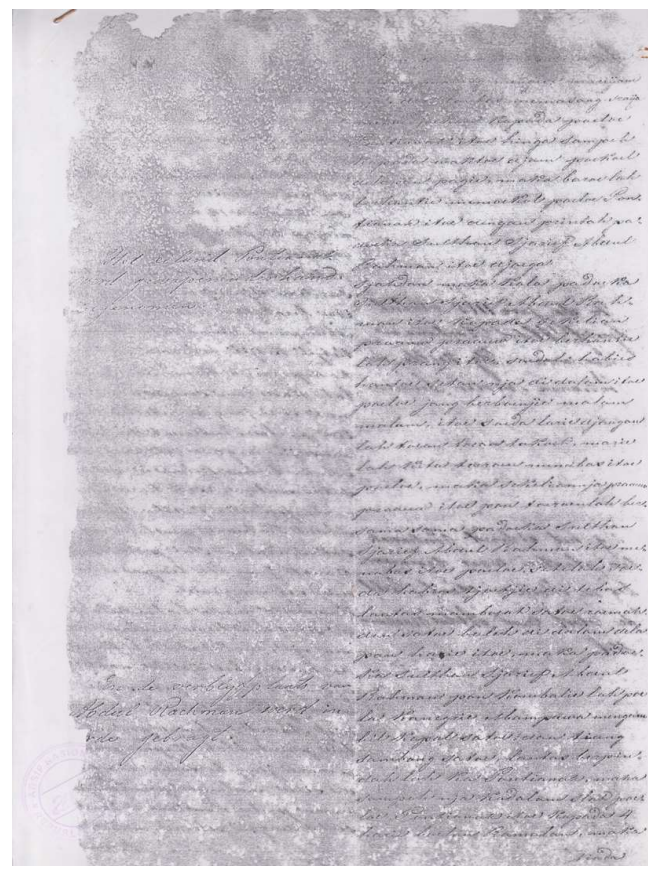

Gambar 2. Catatan Pangeran Bendahara Kesultanan Pontianak tahun 1855.

Sumber: ANRI, Inventaris Arsip Borneo Westerafdeeling No. 233.

Kata-kata khas karya sastra indah berbunga-bunga dan "berlebihan" seperti maka, sjahdan (syahdan), sekelian (sekalian), dan penggunaan partikel -lah tidak ditemukan dalam surat kongsi. Kata-kata khas 'Melayu Tinggi' tersebut terus berkembang dan digunakan dalam karya sastra hingga peralihan abad ke-20 (Rafferty, 1984: 260).
Manuskrip kedua adalah surat pernyataan selamat bagi Sultan Syarif Yusuf Alkadri. Pada surat ini, telaah hanya dilakukan untuk melihat penggunaan kata ganti sapaan bagi Pemerintah Hindia Belanda dalam bahasa surat.

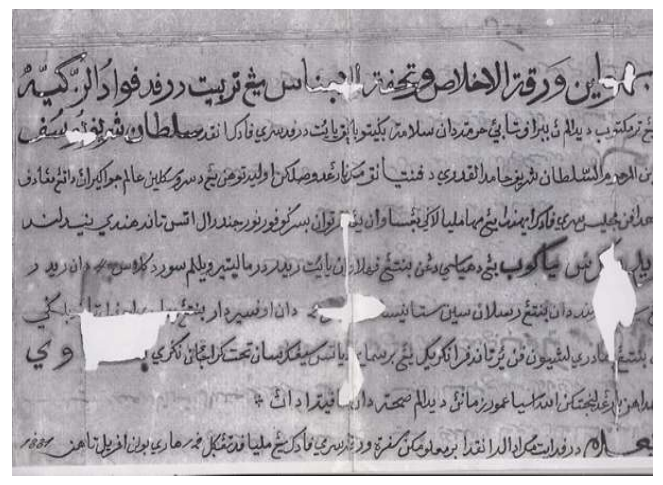

Gambar 3. Surat Ucapan Selamat Atas Pemberian Medali Penghargaan Terhadap Sultan Syarif Yusuf Alkadri dari Pemerintah Hindia Belanda. Sumber: ANRI, Inventaris Arsip Borneo Westerafdeeling No. 310.

Baris keempat menunjukkan penggunaan kata ganti sapaan bagi Pemerintah Hindia Belanda dengan “...Yang Dipertuan Besar Guvernur Jenderal atas Tanah Hindi Nedeland...." Penggunaan kata 'Yang Dipertuan' merupakan kata ganti sapaan yang khas di lingkungan istana Melayu.

Gaya bahasa dan kosakata surat kongsi berbeda dari gaya 'Melayu Istana' menunjukkan bahwa bahasa Melayu Rendah juga digunakan sebagai bahasa diplomatik di Kalimantan pada pertengahan abad ke-19. Keberadaan surat kongsi tersebut memperkuat tesis

\footnotetext{
${ }^{8}$ Transliterasi oleh Dra. Asnaini, staf BPNB Kalbar.
} 
Handep, Vol. 2, No. 1, Desember 2018

yang menyatakan bahasa Melayu sebagai bahasa diplomatik dan bahasa Melayu Rendah tidak hanya digunakan dalam komunikasi massa seperti dalam surat kabar dan karya sastra tetapi juga dalam dokumen resmi berupa korespondensi dengan Pemerintah Hindia Belanda. Hal lain yang perlu dicermati adalah pengguna dan kepada siapa mereka menggunakan bahasa tersebut. Hal ini perlu diketahui untuk melihat kelompok mana saja penutur bahasa dan fungsi bahasa ini bagi kelompok-kelompok tersebut.

Selanjutnya, tulisan ini menelisik faktor sosial-psikologis dari sikap bahasa Kongsi Lanfong. Penelaahan sikap bahasa ${ }^{9}$ bermaksud untuk mengungkap cara kelompok bangsa memandang bahasa mereka sendiri dan bahasa dari kelompok lain (Groeneboer, 1995: 7).

\section{Kongsi Lanfong dan Bahasa Melayu}

Terkait dengan kutipan surat berbahasa Melayu dari Kongsi Lanfong di Mandor, muncul pertanyaan bagaimana mereka dapat menyampaikan surat berbahasa Melayu. Apakah itu berarti komunitas penambang emas tersebut turut sebagai penutur bahasa

${ }^{9}$ Menurut Groeneboer, sikap bahasa selanjutnya dibentuk pula faktor politis, sosial-ekonomi, dan sosial psikologis. Akan tetapi, faktor-faktor tersebut tidak ditelaah lebih jauh dalam tulisan ini (Groeneboer, 1995: 7).
Melayu atau terdapat campur tangan orang lain misalnya penerjemah dalam penulisan surat tersebut.

Khusus di bagian Barat Kalimantan ini, studi Mary Somers Heidhues pun mengungkapkan tidak terdapat kalangan "peranakan" yang cukup besar dan berbahasa Melayu (SomersHeidhues, 2008: 68). Catatan pedagang Inggris yang berdagang dengan koloni Cina di bagian Barat Kalimantan pada 1834 juga menunjukkan ketidakmampuan komunitas penambang akan bahasa Melayu. George Windsor Earl yang langsung mendatangi lokasi Kongsi Monterado mengungkapkan kekhawatirannya akan tipuan dari orang kongsi karena tidak memahami bahasa mereka. Earl juga tidak bisa menanggapi pembicaraan karena baik pemimpin maupun anggota kongsi tidak ada yang mengerti bahasa Melayu. Oleh karenanya, Earl kemudian mempekerjakan dua orang penerjemah, seorang asli Cina yang dapat mengubah dialek Tartar-nya menjadi Cina dan seorang Malaka kelahiran Cina yang menyampaikan percakapan dalam bahasa Melayu (Earl, 1837: 279; 188189).

Meski penuturan Earl tidak berkenaan langsung dengan Kongsi Lanfong namun setidaknya dapat menggambarkan kemampuan bahasa Melayu di kalangan komunitas Cina, khususnya komunitas penambang di pedalaman [bukan di kota bandar]. Akan tetapi, kondisi tersebut tidak stagnan karena tampaknya koloni- 
koloni Cina sadar akan kebutuhan pemahaman bahasa Melayu untuk transaksi dagang. Seperti yang dikisahkan Earl tentang kedatangan seorang Cina kiriman pemimpin Kongsi untuk mempelajari bahasa Melayu pada malam hari setelah komunikasi dagang sebelumnya (Earl, 1837: 288-289). Usaha untuk meningkatkan kemandirian ekonomi kongsi dengan mengadakan perdagangan langsung pada abad ke-19 tentunya akan memengaruhi kemampuan berbahasa mereka di kemudian hari.

Di sisi lain, untuk menaksir riwayat pembuatan surat ada baiknya kita memperhatikan konteks historis dari pembuatan surat. Sejak 1842, Kongsi Lanfong yang berpusat di Mandor berupaya masuk ke Landak untuk meluaskan lokasi penambangan. Langkah tersebut ditolak oleh Panembahan Landak yang menghimpun sejumlah orang Melayu dan Dayak untuk mengusir para penambang Kongsi Lanfong. Konflik antara kedua belah pihak muncul kembali pada 1846 namun dapat diredam lewat mediasi Sultan Pontianak. Konflik baru berakhir pada 1851 dengan diizinkannya Kongsi Lanfong untuk membuka beberapa pertambangan dan menetap di ibu kota Landak. Adapun surat Kongsi berarti dikirim di antara masa konflik. Alasan pengiriman surat kemungkinan karena Pemerintah Hindia Belanda turut campur menghalangi kongsi dan menganggap keberadaan permukiman para penambang di Landak sangat merusak kesejahteraan orang Dayak
(Somers-Heidhues, 2008: 78-79). Dalam suasana konflik, kemungkinan bagi Kongsi Lanfong untuk mendatangkan penerjemah khusus untuk menulis surat cukup kecil. Lantas, apakah dengan begitu Kongsi Lanfong memang telah memiliki anggota yang memiliki kemampuan berbahasa Melayu? Untuk lebih menguatkan penjelasan, mari kita pahami kondisi Kongsi Lanfong terutama terkait dengan interaksinya dengan orang di luar komunitasnya.

Pihak luar yang sangat berpengaruh bagi Kongsi Lanfong adalah Sultan Pontianak. Sultan Pontianak yang memberikan izin bermukim untuk rombongan perintis pimpinan Lanfong pada 1772 sebelum kemudian membentuk kongsi pertambangan emas Lanfong di Mandor pada 1777 (Yuan, 1998: 29).

Berdirinya kongsi di Mandor oleh Lanfong tidak memutuskan hubungan mereka dengan Kesultanan Pontianak. Kongsi Lanfong tetap memiliki kebergantungan pada kesultanan. Posisi Pontianak di muara Sungai Kapuas merupakan pintu masuk menuju Mandor. Area bermukim rombongan Lanfong di Pontianak (kemudian dinamakan Kampung Baru) kemudian difungsikan sebagai tempat singgah bagi imigran Cina yang hendak menjadi penambang di Mandor (SomersHeidhues, 2008: 102-103).

Relasi baik Kongsi Lanfong dengan Kesultanan Pontianak antara lain tergambar pada peristiwa-peristiwa berikut. Pertama, Sultan pertama 
Handep, Vol. 2, No. 1, Desember 2018

Pontianak, Syarif Abdul Rahman Alkadri memberikan hadiah kuda kepada pemimpin Kongsi Lanfong. Kuda yang diperoleh Sultan dari VOC pada 1790 tersebut diketahui dirawat dengan baik saat seorang komisaris Belanda mengunjungi wilayah Kongsi Lanfong pada 1822 (Yuan, 1998: 126). Kedua, saat serangan Kongsi Lanfong terhadap tangsi militer Hindia Belanda di Pontianak pada 1819. Serangan yang digagalkan oleh militer Hindia Belanda malah berujung pada ucapan sumpah setia dan pernyataan pemimpin kongsi, Thaiko Soeng Tshap Pak kepada Sultan Pontianak bahwa mereka bermasalah dengan pemerintah kolonial bukan dengan sultan. Permintaan maaf ini dianggap kongsi telah menyelesaikan masalah sehingga menolak perdamaian terbuka dengan pemerintah kolonial yang ditunjukkan oleh sayembara perburuan kepala orang Eropa (Listiana, 2017: 220-221). Ketiga, Kampung Baru secara faktual diurus sendiri (otonom) oleh Kongsi Lanfong (J.J.K. Enthoven dalam Listiana, 2017: 48).

Relasi baik tersebut bahkan berlanjut saat kelembagaan Kongsi Lanfong dihapus saat pemimpin terakhir kongsi, Kapthai Lioe A Sin meninggal pada 1884 dan pada prosesi pemakaman istri Kapthai Lioe A Sin, Then Sioe Kim Njong di Pontianak. Pada saat kongsi dibubarkan oleh Pemerintah Hindia Belanda dan kemudian diikuti oleh aksi protes dan kerusuhan dari warga kongsi, Kesultanan Pontianak adalah pihak yang dimintai bantuan oleh Then untuk menjadi mediator rekonsiliasi antara masyarakat kongsi dengan pemerintah Hindia Belanda. Permintaan bantuan tersebut disampaikan Then melalui surat yang dikirim oleh utusannya. Sementara pada prosesi pemakaman istri Kapthai, Kesultanan Pontianak memberi penghormatan terakhir berupa penggunaan simbol-simbol kebesaran kesultanan $^{10}$ (J.W.Young dalam Listiana, 2017: 217-218).

Gambaran relasi Kongsi Lanfong dengan kesultanan di atas menunjukkan kebutuhan komunikasi antara kedua pihak. Kebutuhan komunikasi tersebut mengindikasi keberadaan mediator

10 Simbol-simbol kebesaran Kesultanan Pontianak yang digunakan dalam prosesi pemakaman istri Kapthai Lioe A Sin, Then Sioe Kim Njong, berupa penggunaan kain sutera kuning berkalung untaian melati sebagai penutup peti jenazah, penggunaan payung dari kertas emas yang dibalut kain linen putih untuk memayungi bagian kepala peti jenazah, dan pengusungan tombak pemberian sultan Pontianak untuk kapthai Mandor terdahulu (J.W.Young dalam Listiana, 2017: 217-218).

${ }^{11}$ Indikasi ini diperkuat oleh pengiriman surat permohonan bantuan dari Then Sioe Kim Njong kepada Sultan Pontianak. Meski bukan tidak mungkin pula bahwa Then ataupun almarhum Kapthai Lioe sendiri sebenarnya memiliki kemampuan bahasa tersebut. Sayangnya, penulis belum memperoleh informasi atau petunjuk tentang kemampuan bahasa mereka sehingga akan terlalu gegabah mengajukan simpulan tersebut. Terlebih, studi Somers-Heidhues menunjukkan bahwa kapasitas para pemimpin Cina di Kalimantan Barat umumnya tidak seperti di Jawa yang memiliki 
yang menguasai bahasa Melayu di pihak kongsi. ${ }^{11}$

\section{Bahasa Melayu di Nusantara dan Konteks Sosiolinguistik Bahasa Surat}

Bahasa Melayu semakin meluas digunakan oleh penutur bahasanya di Asia Tenggara seiring meningkatnya hubungan mereka dengan bangsa Eropa pada abad ke-16. Digunakan sebagai bahasa perdagangan, bahasa interaksi masyarakat di pasar dan pelabuhan, James T. Collins menyebut bahasa Melayu sebagai lingua franca di Asia Tenggara (Collins, 2005: 28-32). Posisi sebagai bahasa pengantar dipahami pula oleh Groeneboer sebagai penyebab tidak meluas atau diperluasnya bahasa Belanda oleh kaum kolonial Belanda (Wibisono, 2012). Sebagai bahasa perdagangan, bahasa Melayu tumbuh di permukiman Kota Bandar. Di pusat perniagaan ini bahasa Melayu menjadi media komunikasi dari berbagai bangsa, baik masyarakat lokal, orang Eropa, Timur Asing, dan kelompok etnis Bumiputra lain. Oleh karenanya, bahasa Melayu menjadi bahasa yang sangat fleksibel, praktis, dan adaptif (Sumardjo, 2004: 9-10; 20-22). Bahasa Melayu bercampur dengan kosakata dari bahasa berbagai bangsa sehingga menurut Francois Valentyn menjadi

kemampuan bahasa komunikasi penguasa setempat. Hal ini didasarkan oleh cemoohan para pejabat kolonial terhadap opsir-opsir Cina di Kalimantan Barat karena tidak menguasai bahasa Melayu (SomersHeidhues, 2008: 177). tidak begitu murni (Collins, 2005: 4344).

Bahasa Melayu juga menjadi bahasa resmi tulis di lingkungan istana dan media ajar termasuk dalam penyebaran ajaran agama, tidak hanya Islam tapi juga Katolik. Bentuk-bentuk kesusastraan lama seperti syair, pantun, hikayat, dan seloka lahir berkembang di lingkungan kerajaan. Sebut saja Sulalatus Salatin dari Johor, Bustan alSalatin dari Aceh, Hikayat Patani dari Patani, Silsilah Kutai dari Kalimantan Timur, Hikayat Banjar dari Kalimantan Selatan, Sya 'ir Perang Mengkasar dari Sulawesi Selatan. Selain karya sastra, korespondensi antarkerajaan bahkan surat izin perdagangan yang dikeluarkan oleh kerajaan-kerajaan pada abad ke-17 telah menunjukkan kekhasan tata bahasa dan kosakata. Bahasa yang digunakan di istana menurut Valentyn, meski tidak memiliki perbedaan yang sangat jelas dengan bahasa Melayu di luar istana kecuali sangat bergaya, banyak bercampur dengan kosakata bahasa Arab. Perkembangan bahasa yang digunakan pada sastra Melayu abad ke17 ini dipandang sebagai bahasa yang ideal dan dijadikan patokan bagi produk sastra Melayu berikutnya (Collins, 2005: 28-32; 44-52).

Perkembangan bahasa Melayu mengarah pada pembentukan dua kategori di atas, bahasa 'Melayu Dagang' untuk pergaulan masyarakat luas dan bahasa 'Melayu Ideal' untuk kalangan terbatas. Dua kategori ini 
Handep, Vol. 2, No. 1, Desember 2018

kemudian memiliki kelompok penuturnya dan setiap kelompok menghasilkan produk bahasanya masing-masing, terutama berkembang sejak abad ke- 19 .

Produk bahasa 'Melayu Ideal' terkenal antara lain Tuhfat al-Nafis karya Raja Ali Haji tahun 1868, Syair van Ophuysen karya Raja Haji Sulaiman, bahan ajar di sekolahsekolah koloni Belanda berjudul Cakap-Cakap Rampai-Rampai Bahasa Melayu Johor karya pejabat Pemerintah Hindia Belanda H. Von de Wall dan Haji Ibrahim dari Johor (Collins, 2005: 7980 ), beberapa surat kabar yang memuat kisah-kisah Melayu Klasik yang banyak menceritakan kisah nabi-nabi seperti koran Bintang Oetara yang dikelola oleh Roorda van Eysinga pada 18561857, dan cerita terjemahan seperti Hikajat Tjeritra Kasih Sajang oleh Dja Endar Moeda di Padang tahun 1895 (Jakob Sumardjo, 2004: 17; 28).

Kelompok penutur atau pengguna pengembangan bahasa Melayu yang disebut Collins sebagai bahasa 'Melayu Klasik' biasanya hanya para ratu, pejabat istana, dan para sarjana. Jenis yang disebut pula sebagai bahasa 'Melayu Baku' ini digunakan dalam apa yang sebelumnya disebut kesusastraan lama (Collins, 2005: 44). Kegiatan penerbitan buku panduan pengajaran sekolah dan kegiatan penerjemahan dari lingkungan pribumi didukung oleh penerbitan pemerintah kolonial, Balai Poestaka baik dalam bahasa Melayu Tinggi, bahasa Jawa, maupun bahasa Sunda (Sumardjo, 2004: 28).
Sementara produk bahasa 'Melayu Dagang' adalah koran-koran yang meluas di kota-kota niaga, roman, novel, dan cerita pendek. Terbitan koran berbahasa 'Melayu Dagang' yang dimulai oleh Soerat Kabar Batawi's pada 1858 tidak hanya bersifat dagang tapi juga memuat karya sastra berupa cerita pendek, penceritaan kembali hikayat lama, syair dan pantun yang bersifat epik dan lirik, juga kritik terhadap pemerintah (Sumardjo, 2004: 17-18). Ada roman terjemahan dari novel Barat dan Cina, seperti LawahLawah Merah pada 1875 yang kemungkinan ditulis oleh ayah F. Wiggers dan Bintang Toedjoeh dengan bahasa Melayu Cina pada 1880-an oleh Lie Kim Hok. Ada novel Hikayat Ali Saleh Anak dari Ali Sarin karya R.M.H.J.S. Kartawinata tahun 1897. Menyusul kemudian F.D.J. Pangemanan pada 1900 dengan novel Tjerita Si Tjonat R.M.Tirto Adhisoerjo pada 1902 dengan cerita pertamanya Perboeatan Seorang Gadis Riwajat pada Masa Sekarang, Mas Marco Kartodikromo pada 1914 dengan novel Mata Gelap tiga penulis terakhir adalah juga pewarta yang menulis opini menggunakan bahasa 'Melayu Dagang' dan turut mengantar nasionalisme dan gerakan kebangsaan melalui pers dan sastra pada awal abad ke-20 (Sumardjo, 2004: 19-37; Salmon dalam Suryadinata (ed.), 1996: 215216).

Karya sastra dengan bahasa 'Melayu Dagang' di atas dan banyak 
karya dengan genre serupa adalah kreasi orang-orang Indo-, orang-orang Cina terutama peranakan di Jawa yang sebagian besar Hokkian, dan pribumi dari beragam etnis. Mereka menggunakan bahasa Melayu yang berkembang di lingkungannya. Kalangan peranakan yang produktif menghasilkan karya sastra dengan bahasa yang disebut 'Melayu Cina' kebanyakan adalah keturunan Cina yang sudah tidak menguasai bahasa leluhur mereka. Riset Claudine Salmon yang dikutip Jakob Sumardjo menunjukkan bahwa mereka adalah penulis dari kota-kota di Jawa dan sebagian dari Sumatera (Bengkulu, Padang, dan Medan), dan sedikit dari Kalimantan (Banjarmasin). Adapun penulis lain menggunakan bahasa Melayu yang berkembang di daerahnya dan dengan mudah menyerap tata bahasa asing baik Tionghoa, Eropa, maupun bahasa-bahasa daerah setempat. Karena itu, muncul sebutan 'Melayu Adukan' atau 'Melayu Rusak' untuk bahasa Melayu yang tidak memiliki tata bahasa baku ini. Bahasa 'Melayu Rusak' bukan hanya bahasa tulis namun aktif dituturkan oleh penduduk kota dan kalangan pers baik orang Belanda, Indo-, Cina, maupun bumiputra sendiri. Karya sastra atau pers yang terbit menggunakan bahasa 'Melayu Rusak' ini kebanyakan didukung oleh penerbitan dan percetakan Indo dan Cina (Sumardjo, 2004: 20-22; 39-40).
Perkembangan bahasa pada mulanya bukan merupakan perhatian utama pemerintah kolonial. Perhatian secukupnya mencakup kewajiban setiap pejabat pemerintahan untuk mampu berbahasa Melayu dan bahasa setempat lainnya. Akan tetapi, di akhir abad ke19 pemerintah akhirnya memerhatikan juga bahkan mendirikan suatu lembaga pemerintahan untuk urusan bumiputra yang salah satunya mengurusi perihal bahasa. Ejaan van Ophuijsen adalah hasilnya, untuk kemudian diterapkan pada 1901 sehingga memerdalam campur tangan pemerintah pada bahasa. Bahasa Melayu dan segala variannya (Melayu Jawa, Melayu Riau, Melayu Sunda, Melayu Betawi, dan Melayu Cina) sebagai lingua franca layak pemerintah kembangkan sebagai alat pemerintah berkuasa dan menjalin komunikasi dengan penduduk yang dikuasainya. Surat-menyurat, pengumuman, perjanjian kerja sama, dan kesepakatan politik yang penguasa bumiputra jalin dengan pemerintah memperlihatkan tiga bahasa yang bersanding: Belanda, Jawa, dan Arab Melayu. Sebagai pilihan, pemerintah memilih Riouw Maleijsch atau Melayu Riau sebagai ragam bahasa Melayu yang van Ophuijsen kembangkan. Pemerintah jadikan Melayu Riau

\footnotetext{
12 Melayu Rendah kita kenal pula sebagai 'Melajoe Kaoem', 'Melajoe Pasar', 'Melajoe Betawi', dan juga 'Melajoe Cina'. Sekalipun Pemerintah menggagas 'Melayu Tinggi' bahkan mendirikan lembaga bahasa seperti Bureau van de Volkslectuur atau Balai Pustaka, tetap saja Pemerintah berkomunikasi dengan Bumiputra dalam Melayu Rendah (Sumardjo, 2004: 20-21).
} 
Handep, Vol. 2, No. 1, Desember 2018

sebagai Hoog Maleisch atau Melayu Tinggi, sedangkan ragam Melayu lainnya sebagai Laag Maleisch atau Melayu Rendah ${ }^{12}$. Melayu Tinggi yang pemerintah pilih pun menjelma menjadi ejaan van Ophuijsen sebagaimana nama penggagasnya Charles Adriaan van Ophuijsen (Wibisono, 2013). Campur tangan pemerintah terus berlanjut seiring pendirian Balai Pustaka pada 1917 sehingga kelak melahirkan babak sastra modern. Balai Pustaka-lah yang mencampuri wawasan penduduk Hindia Belanda melalui lembaga pendidikan (Sumardjo, 2004: 35).

\section{PENUTUP}

'Melayu Rendah' merupakan sebutan untuk dialek yang umumnya digunakan oleh komunitas Cina peranakan, terutama di Jawa. 'Melayu Rendah' mulanya sebatas bahasa tutur yang lahir di wilayah Semenanjung Malaya. Di tempat lahirnya, tutur Melayu mendapatkan pengaruh bahasa Cina lebih banyak sehingga kemudian disebut 'Melayu Baba'. Sementara di Hindia Belanda, tutur Melayu lebih mendapatkan pengaruh bahasa Melayu dan dikenal sebagai 'Melayu Rendah'. Bahasa 'Melayu Rendah' diketahui berkembang sebagai bahasa tulis sejak paruh kedua abad ke-19. Bahasa Melayu yang digunakan dalam Kongsi Lanfong tahun 1848 cenderung lebih berkarakter 'Melayu Rendah' meski mengandung karakter 'Melayu Baba' khas Semenanjung Malaya.
Penggunaan bahasa Melayu Rendah pada Kongsi Lanfong pada 1848 menunjukkan bahwa sebagai bahasa, ia telah digunakan dalam korespondensi formal dengan pemerintah kolonial. Secara sosiologis, kuatnya karakter 'Melayu Rendah' pada surat tersebut menunjukkan preferensi bahasa Kongsi Lanfong yang pemimpinnya dikenal karib dengan penguasa Melayu Pontianak.

\section{DAFTAR SUMBER}

Alamsyah. 2018. "Kontribusi Arsip dalam Rekonstruksi Sejarah (Studi di Keresidenan Jepara dan Tegal Abad Ke-19)," dalam ANUVA: Jurnal Kajian Budaya, Perpustakaan, dan Informasi Vol. 2 (2), hlm. 153-163.

ANRI, Inventaris Arsip Borneo Westerafdeeling No. 177, Ikhtisar Singkat. Mengenai Industri dan Perdagangan di Borneo Tahun 1849.

, Inventaris Arsip Borneo Westerafdeeling No. 233 Th. 1852, Catatan Pangeran Bandahara Tahun 1850.

, Inventaris Arsip Borneo Westerafdeeling No. 310 Th. 1881, Surat Sultan Pontianak ke Gubernur Jendral Landsburg tanggal 7 Agustus 1881.

. TT. Inventaris Arsip Borneo Westerafdeeling. Jakarta: ANRI. 
. 2016. Panduan Penelusuran Arsip Statis. Jakarta: ANRI.

Collins, James T. 2005. Bahasa Melayu Bahasa Dunia, Sejarah Singkat. Jakarta: Yayasan Obor Indonesia.

Gaillet, Lynee Lewis. 2010. “Archival Survival: Navigating Historical Research," dalam Ramsey, Alexis E. et al. (ed.), Working in the Archives: Practical Research Methods for Rhetoric and Composition. Carbondale: Southern Illnois University Press.

Earl, George Windsor. 1837. The Eastern Seas or Voyages and Adventures in The Indian Archipelago in 1832-33-34. London: Wm. H. Allen and Co.

Groeneboer, Kees. 1995. Jalan ke Barat, Bahasa Belanda di Hindia Belanda 1600-1950: Sejarah Politik Bahasa. Jakarta: Erasmus Taalcentrum.

http://www.sejarah-nusantara. anri.go.id/id/diplomatic-letters1683-1744/, diakses pada Maret 2018.

Listiana, Dana. 2017. Sistem Pacht dan Perluasan Negara Kolonial di Pontianak 1819-1909. Tesis. Yogyakarta: Fakultas Ilmu Budaya Universitas Gadjah Mada.

Lohanda, Mona. 2011. Membaca Sumber Menulis Sejarah. Yogyakarta: Ombak.
Poerwanto, Hari. 2005. Orang Cina Khek dari Singkawang. Jakarta: Komunitas Bambu.

Rafferty, Ellen. 1984. "Languages of the Chinese of Java: An Historical Review," dalam The Journal of Asian Studies, Vol. 43, No. 2, hlm. 247-272.

Salmon, Claudine. 1996. "Asal-Usul Novel Melayu Modern: Tjhit Liap Seng (Bintang Tujuh) Karangan Lie Kim Hok (1886-1887)," dalam Leo Suryadinata (ed.), Sastra Peranakan Tionghoa Indonesia. Jakarta: Grasindo.

Shellabear, W.G. 1913. "Baba Malay. An Introduction to the Language of the Straits-born Chinese," dalam Journal of the Straits Branch of the Royal Asiatic Society, No. 65, hlm. 49-63.

Somers-Heidhues, Mary. 2008. Penambang Emas, Petani, dan Pedagang di Distrik Tionghoa Kalimantan Barat. Jakarta: Yayasan Nabil.

Sumardjo, Jakob. 2004. Kesusastraan Melayu Rendah Masa Awal. Yogyakarta: Galang Press.

Stoler, Ann Laura. 2000. Along the Archival Grain: Epistemic Anxieties and Colonial Common Sense. Princeton: Princeton University Press. 
Tan Chee-Beng. 1980. "Baba Malay Dialect," dalam Journal of the Malaysian Branch of the Royal Asiatic Society, Vol. 53, No. 1 (237), hlm. 150-166.

Wibisono, Joss. 23 Januari 2012.

"Bahasa Belanda di Nusantara:

Dibayangi VOC," dalam Tempo. . 8 September 2013.

"Melajoe Belanda," dalam Tempo.

Yuan Bingling. 1998. Chinese Democracies: A Study of The Kongsis of West Borneo 17761884. Tesis. Leiden: Leiden University. 